\title{
Investigation of Floral Dye Extracts as Dyeing Material for Textile Fabrics with Bio Mordant for Sri Lankan Textile Industry [Investigación de extractos de tintes florales como material de teñido para telas textiles con biomordiente para la industria textil de Sri Lanka]
}

\author{
Samudrika U.G. Wijayapala \\ Department of Textile \& Clothing Technology, Faculty of Engineering, University of Moratuwa, \\ Sri Lanka \\ samu@uom.lk
}

Received: 06 October 2020; Accepted: 12 October 2020; Published: 12 October 2020

\begin{abstract}
Resumen
En Sri Lanka se cultivan una gran cantidad de flores. Estas flores se utilizan como decoración o como ofrenda a Buda y Dios. Un informe de la encuesta revela que el $40 \%$ de la producción total de flores no se vende y se desperdicia todos los días, que se arrojan al agua o se tiran, lo que también genera contaminación del agua y contaminación ambiental. Estas flores desperdiciadas se pueden usar de varias maneras y podemos obtener riqueza de los materiales de desecho. Estas flores desperdiciadas se utilizan en la extracción de tintes de colores de estas flores y se utilizan en la industria textil para teñir y la porción de agua residual se puede utilizar como biofertilizantes. Se puede extraer un tinte de colores de las flores para teñir la fibra textil. Estos tintes florales son ecológicos y no tienen una acción alérgica en la piel como el tinte sintético. Además, el procedimiento es muy rentable y, dependiendo de él, se pueden establecer industrias a pequeña escala y a gran escala. Teniendo en cuenta la importancia de los eco textiles y su demanda en el mercado nacional e internacional y para superar el problema de la contaminación ambiental, reacciones alérgicas al hombre, se llevó a cabo la presente investigación para introducir al uso de tintes florales para la tintura de blanqueados. tela de algodón y probó sus propiedades de solidez del color.
\end{abstract}

Palabras clave: Flor, tinte floral, materiales de desecho, contaminación ambiental.

\begin{abstract}
In Sri Lanka a huge amount of flowers are cultivated. These flowers are used as decoration purposes or for offering to Buddha and God. A survey report reveals that $40 \%$ of the total productions of flowers are unsold and wasted everyday which are thrown in water or dumped which also creates water pollution as well as environmental pollution. These wasted flowers can be used in various ways \& we can get wealth from waste materials. These wasted flowers are used in extraction of colourful dyes from these flowers and use it in textile industry for dyeing purposes and the residual water portion can be used as bio-fertilizers. Colourful dye can be extracted from flowers for dyeing textile fibre. These floral dyes are eco-friendly \& it has no allergic action on skin like synthetic dye. Moreover the procedure is very cost-effective and depending on it small scale Industry as well as Large scale Industry can be set up. Keeping in view the importance of eco textiles and their demand in the national and international market and to overcome the problem of environmental pollution, allergic reactions to man- kind, and the present investigation was carried out to introduce to use floral dyes for dyeing of bleached cotton fabric and tested its colour fastness properties.
\end{abstract}

Keywords: Flower, Floral dye,waste materials, Environmental pollution 


\section{SE}

Vol. 4, $\mathrm{N}^{\circ} 2,2020$

\section{Journal of Sciences and Engineering}

Copyright (c) 2020, CINCADER.

ISSN 2523-9503

DOI: https://doi.org/10.32829/sej.v4i1.126
Centre of Research and Training for

Regional Development Online at www.journals.cincader.org

\section{Introduction}

Dyeing of textiles mean giving them a colour which is of comparative permanence. It implies that it should not be possible to wash the colour out easily in laundering, nor should it fade rapidly when exposed to light. It is now suspected that many of the synthetic dyes are carcinogenic in nature and havoc in life systems. It's ironic that Europe that initiated the advent of synthetic dyes in the first place woke up the dangers of these agents and turning down for a few members of these classes, proven to be harmful to life forms (Paker $\mathrm{CH}$ (2002-2003); saroj et al., 2013; Vadwala et al., 2017; Gyanendra, 2015)

Herbal dyes however produced from floral extracts are economical and solve the above problems. These herbal dyes are not toxic, no allergic to human health, easily available and more economical. Some natural sources for dye produce truly exquisite shades and economical to purchase than chemical dyes (Angel R. and Chadha Y. R., 1978). Flowers of Mari-gold, igsora, Bougainvillea, canas etc. have been extensively used for dyeing fabric. In this research floral dyes from China rose, Aprajitha flower, Kudalu (balsam Flower) were used to dye cotton fabrics. In the present work three flower extracts were used to dye the cotton fabrics at optimized conditions by using a single mordant and the color fastness of the dyed fabrics were also evaluated by using following standards (Vankar, 2000; Angel and Chadha, 1978).

- Wash fastness - ISO 105-CO1/CO2/CO3/CO4/CO5

- Rub fastness - ISO 105-X12

- $\quad$ Light fastness - ISO 105-B02

- $\quad$ Fastness to perspiration - ISO 105-E04

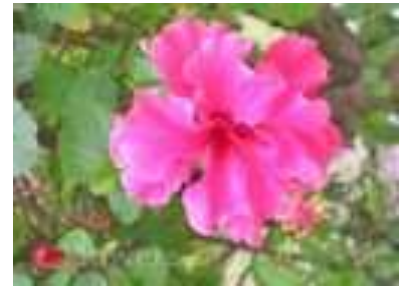

Figure 1 - China Rose

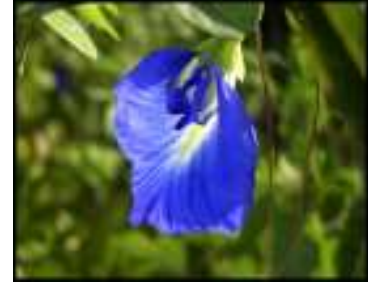

Figure 2 - Aparajitha Flower

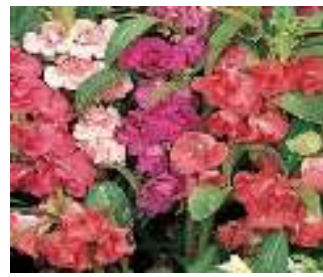

Figure 3 - Balsam Flowers

\section{Materials and Methods}

\subsection{Materials}

Bleached cotton fabrics.

\subsection{Sample Collection}

The extraction of the dye was carried out in two different flowers. These flowers were collected from nearby areas at Moratuwa, Piliyandala area in Sri Lanka. The chosen flowers were China rose, Aparajitha flower, Balsam Flower. 


\section{Journal of Sciences and Engineering}

Vol. 4, $\mathrm{N}^{\circ}$ 2, 2020

Copyright (C) 2020, CINCADER.

ISSN 2523-9503

DOI: https://doi.org/10.32829/sej.v4i1.126

Table 2 - Sample Description

\begin{tabular}{|c|l|l|l|l|l|l|}
\hline $\begin{array}{c}\text { Sample } \\
\text { No. }\end{array}$ & $\begin{array}{c}\text { Common } \\
\text { Name }\end{array}$ & \multicolumn{1}{|c|}{$\begin{array}{c}\text { Botanical } \\
\text { Name }\end{array}$} & \multicolumn{1}{|c|}{ Family } & $\begin{array}{c}\text { Part } \\
\text { Used }\end{array}$ & Source & Cost \\
\hline 01 & Shoe flower & $\begin{array}{l}\text { Hibiscus rosa- } \\
\text { sinensis }\end{array}$ & Malvaceae & flower & $\begin{array}{l}\text { Temples, } \\
\text { Kovils }\end{array}$ & Free \\
\hline 02 & Butterfly pea & Clitoria ternatea & Fabeceae & flower & $\begin{array}{l}\text { Temples, } \\
\text { Kovils }\end{array}$ & Free \\
\hline 03 & $\begin{array}{l}\text { Balsam } \\
\text { Flower }\end{array}$ & $\begin{array}{l}\text { Impatiens } \\
\text { balsamina }\end{array}$ & Balsaminaceae & flower & $\begin{array}{l}\text { Temples, } \\
\text { Kovils }\end{array}$ & Free \\
\hline
\end{tabular}

\subsection{Extraction of Dye}

The collected flower materials were shade dried until the moisture was reduced to below $3 \%$. The dried flowers were grinded and sieved to obtain the fine powder. The dyes from different flowers were extracted separately in the proportion of $1: 8$ of flower by aqueous extraction and the extraction process was carried out at a temperature range of $80-85^{\circ} \mathrm{C}$ for 1 hour. Colouring materials from the flowers are extracted to dyeing the fibre Experimentally it is seen that at temperature range $80^{\circ} \mathrm{C}-90^{\circ} \mathrm{C}$ and time 1 hrs., the extraction is better, so this is the optimized time and temperature for extraction process.

\subsection{Mordanting of Textile Fiber}

The sample of cotton was mordanted before the dyeing. For mordanting sepalika (Nyctanthes arbor-tristis) as bio-mordant was used. The fiber was mordanted for $1 \mathrm{hrs}$. at the temperature ranges $80-85^{\circ} \mathrm{C}$. After mordanting, the samples of clothes were taken out, squeezed and then immersed in the dye bath.

\subsection{Procedure of Dyeing of cloth}

The mordanting samples were dyed at Material to liquor ratio of 1:50 for $1 \mathrm{hrs}$. at a temperature of $800 \mathrm{C}$ and after completion of dyeing; samples were taken out and dried. It is allowed to be aged for a fixed time, and after that soaped with $2 \mathrm{~g} / \mathrm{l}$ non-ionic soap at room temperature for 10 minutes followed by rinsing and line dying.

\subsection{Determination of colour fastness}

Dyed Textiles Colour fastness is the resistance of a material to change any of its colour characteristics or extent of transfer of its colorants to adjacent white materials in touch. The colour fastness is usually rated using greyscale either by loss of depth of colour in original sample or by staining adjacent white material. However, among all types of colour fastness, light fastness, wash fastness and rub fastness are considered most important for any textiles; perspiration fastness is more useful for apparels only (Samanta and Agarwal, 2009).

The colour fastness of the samples dyed with flower extract were tested in terms of wash, rub, light and perspiration fastness respectively according to the following standards and the visual assessment methods were carried out to assess the fastness properties.

\section{- Wash fastness - ISO 105-CO1/CO2/CO3/CO4/CO5}

Dyed fabric samples were cut in $10 \times 4 \mathrm{~cm}$ and placed between two pieces of non dyed white samples (control). These three pieces were held together by stitching round the edges. The pre-heated soap solution (Tide at $55^{\circ} \mathrm{C}$ ) in the ratio of $1: 50$ i.e $0.5 \mathrm{~g} / 25 \mathrm{~mL}$ water, was taken in a vessel added $1.0 \mathrm{~g}$ of sandwiched fabric for 45 minutes Then the specimen was removed and rinsed in cold water. (Samanta and Agarwal, 2009) 


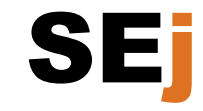

Vol. 4, $\mathrm{N}^{\circ} 2,2020$

\section{Journal of Sciences and Engineering}

Copyright (C) 2020, CINCADER.

ISSN 2523-9503

DOI: https://doi.org/10.32829/sej.v4i1.126

\section{CINCADER}

Centre of Research and Training for

Regional Development

Online at www.journals.cincader.org

- Rub fastness - ISO 105-X12

The rub fastnesses of the dyed fabrics were carried out by rubbing the fabrics manually and checking for fading of color by using Crock meter. Dyed fabric specimens were rubbed against dry and wet white fabric swatch back and forth of ten complete cycles (Vankar, 2000; Vadwala et al., 2017; Fibre2fashion.com, 2020).

- $\quad$ Light fastness - ISO 105-B02

The fabric was exposed to artificial day light for 24 hours. After $24 \mathrm{hrs}$, colour fastness to light was evaluated by comparison of colour change of the exposed portion to the unexposed original material against grey scale . Based on the standard, the assessment of colour fastness was measured (Tripathi et al., 2009).

- Fastness to perspiration - ISO 105-E04

This perspiration refers to the ability not to fade and not to stain when dyed fabric is perspired. The garments which come into contact with the body where perspiration is heavy may suffer serious local discoloration. This test is intended to determine the resistance of colour of dyed textile to the action of acidic and alkaline perspiration. This kind of test is specially applied for the sportswear and heavy dresses which is used specially. Normal cloths are also tested by perspiration test. This test is designed for use in assessing the fastness of the dyed, printed, or otherwise coloured textile yarns and fabrics of all kinds to the effects of human perspiration. Any change in colour of the specimens and staining of the multifibre is then assessed with the corresponding Grey scales for colour change and staining.

The assessment of colour fastness is carried out by assigning ratings for Change in colour (of the test specimen) and staining (of adjacent fabric) (Mishra P and Patni V, 2011).

\section{Results}

Following table illustrates the fastness properties of naturally dyed cotton fabrics under conventional conditions without bio mordant.

Table 2. Fastness properties of dyed cotton fabrics under conventional conditions without mordanting

\begin{tabular}{|l|c|c|c|c|c|c|}
\hline \multirow{2}{*}{ Dye Used on Cotton Fabrics } & \multicolumn{7}{|c|}{ Fastness values } \\
\cline { 2 - 8 } & WF & Per acidi & Perbasic & Rubdry & Rub wet $^{\prime}$ & LF \\
\hline China Rose & 3 & 3 & 3 & 3 & 3 & $3-4$ \\
\hline Aparajitha Flower & 3 & 3 & $3-4$ & $3-4$ & $3-4$ & 3 \\
\hline Bixa & 3 & 3 & 3 & $3-4$ & 3 & $3-4$ \\
\hline
\end{tabular}

Table 3. Fastness properties of dyed cotton fabrics under pre mordanting conditions with Sepalika (Nyctanthes arbor-tristis) as a natural bio mordant 


\section{Journal of Sciences and Engineering}

Vol. 4, $\mathrm{N}^{\circ} 2,2020$

Copyright @ 2020, CINCADER.

ISSN 2523-9503

DOI: https://doi.org/10.32829/sej.v4i1.126

\begin{tabular}{|l|c|c|c|c|c|c|}
\hline Dye used on cotton fabrics with & \multicolumn{7}{|c|}{ Fastness values } \\
\cline { 2 - 8 } Sepalika (Nyctanthes arbor-tristis) & WF & Per acid & Perbasi & Rubdry & Rub & LF \\
\hline China Rose & 4 & 4 & 4 & 4 & 4 & 4 \\
\hline Aparajitha Flower & 4 & 4 & 4 & 4 & 4 & 4 \\
\hline Balsam Flower & $4-5$ & 4 & 4 & 4 & 4 & $4-5$ \\
\hline
\end{tabular}

$(\mathrm{WF}=$ wash fastness, $\mathrm{LF}=$ light fastness, Per $=$ Perspiration fastness, $\mathrm{Rub}=$ Rubbing fastness

Table 2 shows the medium colour fastness properties of fabrics which indicates that the ability of substantivity of the dye molecules and fibre can be improvised by adding mordants. The wash and perspiration of acid media values are same and other values are different between each other. Table 3 indicates the good colour fastness properties in all fastness tests carried out. The colour fastness properties of all three dyes used are enhanced as a result of the addition of pre mordanting conditions with Sepalika (Nyctanthes arbor-tristis). This shows that the Sepalika is the mordant which helps to bind the dye molecules with fibre resulting in stronger bonds. The bio mordant, Sepalika gave very good colour fastness to washing and light when dyed with Balsam flower.

The results of this research showed that the different flowers can be used as a dye for fabrics. Naturally, dyed cotton fabrics with flower extracts treated under conventional conditions without mordanting showed very poor wash fastness, perspiration fastness, Rub fastness and Light fastness properties. But the treatment with aqueous extracts of fresh and old Sepalika flowers enhance the fastness properties of naturally dyed fabrics in pre-mordanting conditions with the conventional optimum dyeing parameters.

\section{Conclusions}

The results of this research showed that the different flowers can be used as a dye for fabrics. Naturally dyed cotton fabrics with flower extracts treated under conventional conditions without mordanting showed very poor wash fastness, perspiration fastness, Rub fastness and Light fastness properties. But the treatment with aqueous extracts of fresh and old Sepalika flowers enhance the fastness properties of naturally dyed fabrics in pre-mordanting conditions with the conventional optimum dyeing parameters.

Thus it can be concluded that the dyed fabrics of extracts of wasted flowers modanted with Sepalika (Nyctanthes arbor-tristis) flowers are well suited for textile dyeing. Bio-mordant like Sepalika can be used to enhance the fastness properties of dyed fabrics. These excellent fastness properties revealed that it can be used in small scale industry as well as large scale industry. The process is economically viable as the raw materials are available with low cost and cost of production is also very low.

\section{Acknowledgments}

The author wishes to acknowledge the University of Moratuwa in Sri Lanka for the Support for testing and financial assistance through SRC grant. 


\section{Journal of Sciences and Engineering}

Vol. 4, $\mathrm{N}^{\circ} 2,2020$

Copyright (c) 2020, CINCADER.

ISSN 2523-9503

DOI: https://doi.org/10.32829/sej.v4i1.126

\section{References}

Angel R. and Chadha Y. R., 1978, The Wealth of India. Raw Materials,Kew Bull., 32(4),802.

Fibre2fashion.com, 2020. Natural Floral Dye, Coloring Textile Fiber, Marigold Flower Dyeing, Eco Friendly Dye,<www.fibre2fashion.com/industry-article/3333/dyeing-of-textile-fibre-using- marigoldflower> accessed 10.13 .

Gyanendra T., Mukesh K.Y., Prabhat P., Shardendu M., 2015, Natural dyes with future aspects in dyeing of Textiles: A research article, Int.J. PharmTech. Res., 8(1), 096-100.

Samanta A.K.,Agarwal P., 2009, Application of Natural Dyes on Textiles, Ind. J. Fibre andText. Res. 34, 384-399.

Mishra P and Patni V, 2011, Extraction and Application of Dye Extracted from Eriophyid Leaf Galls of Quercus Leucotrichophora - A Himalayan Bluejack Oak, African J. Biochem Research, 5(3), 90-94.

Raja D., Arputharaj A., Prakash C., Ramesh B. and Koushik C.V., 2010, Study on Dyeing Behaviour of Cotton/Organic Cotton Knitted Fabrics. Indian J. Sci Technol, 3(7), 746-751.

Saroj Y, Neelam R, Saroj SJ, Krishna k, 2013, Natural Dye Powder: An Easy Technique for Eco- Dyeing, Res. J. Recent Sci., 2, 308-311.

Tripathi, Hemant G., Yadav, S.R., 2009, Biodiversity in India. Environment Awareness. Vol. 32 (1-2):15-17

Vadwala Y., Kola N., and Patel S.M., 2017, Natural Dyes Extracted from Waste Leaves Of Terminalia Catappa Locally Known as Tropical Almond and Its Application on Silk Fabrics Pre-treated With EcoFriendly and NonEco-Friendly Mordants, Int. J. Res., 5(5).

Vankar P. S., 2000, Chemistry of Natural Dyes,Resonance, 5(10), 73-80. 